\title{
$\beta$-cell self-destruction and extremely complicated and still unknown etiopathogenesis of type 1 diabetes
}

Proces autodestrukcji komórek $\beta$ trzustki oraz niezwykle skomplikowana i wciąż nieznana etiopatogeneza cukrzycy typu 1

\author{
${ }^{1}$ Artur Chwalba, ${ }^{2}$ Aleksandra Pilśniak, ${ }^{3}$ Ewa Otto-Buczkowska \\ 1'Department of Pharmacology, Medical University of Silesia, Poland \\ ${ }^{2}$ Inpatient Department of Radiation and Clinical Oncology, Maria Skłodowska-Curie Institute - Oncology Center, \\ Gliwice Branch, Poland \\ ${ }^{3}$ Medical Specialist Centre in Gliwice, Medical Specialist Centre in Gliwice, Poland
}

\begin{abstract}
Type 1 diabetes is based on apoptosis, which leads to $\beta$-cell death. Factors triggering apoptosis processes are very diverse and currently not fully explained. The main role is attributed to genetic and environmental factors. Genetic studies have shown that the inherited propensity for type 1 diabetes is multi-genetic. Environmental factors modify the response to their own antigens, but are probably not necessary to start the autoaggression process. The effect of $\beta$-cell destruction is confirmed by the appearance of autoantibodies in the blood. The paper presents a review of the available literature regarding the self-destruction of pancreatic $\beta$-cells. The aim of the study was to draw attention to the extremely complicated and still unknown etiopathogenesis of type 1 diabetes by reviewing current literature related to the above topic. The goal is to acquire the knowledge necessary to develop and implement causal treatment for diabetes. At the moment, unfortunately, we do not have safe, innovative therapy methods in the field of diabetes prevention. Intensive research on the etiopathogenesis of type 1 diabetes is an extremely important field of medical research.
\end{abstract}

Key words:

apoptosis, autoantibodies, type 1 diabetes, $\beta$-cell destruction, immunological markers.

\section{Streszczenie}

Etiopatogeneza cukrzycy typu 1 opiera się na apoptozie, która prowadzi do śmierci komórek $\beta$ trzustki. Czynniki uruchamiające procesy apoptozy są bardzo zróżnicowane i do tej pory nie zostały w pełni wyjaśnione. Główną rolę przypisuje się czynnikom genetycznym oraz środowiskowym. Badania genetyczne wykazały, że dziedziczna skłonność do cukrzycy typu 1 jest poligenowa. Czynniki środowiskowe modyfikują odpowiedź na własne antygeny, ale prawdopodobnie nie są konieczne do rozpoczęcia procesu autoagresji. Efekt niszczenia komórek $\beta$ potwierdza pojawienie się autoprzeciwciał we krwi.

W pracy przedstawiono przegląd dostępnej literatury dotyczącej autodestrukcji komórek $\beta$ trzustki.

Celem pracy było zwrócenie uwagi na niezwykle skomplikowaną i nadal niepoznaną etiopatogenezę cukrzycy typu 1 poprzez przegląd aktualnej literatury związanej z tym tematem.

Bardzo ważne jest zdobycie wiedzy niezbędnej do opracowania i wdrożenia leczenia przyczynowego cukrzycy. Obecnie, niestety, nie ma bezpiecznych, innowacyjnych metod terapii w zakresie profilaktyki cukrzycy. Zatem intensywne badania nad etiopatogenezą cukrzycy typu 1 są niezwykle ważną dziedziną badań medycznych.

\section{Słowa kluczowe:}

apoptoza, autoprzeciwciała, cukrzyca typu 1, zniszczenie komórek $\beta$, markery immunologiczne. 


\section{Introduction}

Type 1 diabetes afflicting millions of people worldwide is based on apoptosis, which leads to $\beta$-cell death [1-4]. The destruction of these cells in people with risk factors usually begins earlier, and is often ahead of the clinical manifestation of diabetes. Factors triggering apoptosis processes are very diverse and currently not fully explained [1-4]. The main role is attributed to genetic and environmental factors. At the same time, their role in the process of starting apoptosis is assessed differently by various authors. Based on a review of the current literature on the self-destruction of pancreatic $\beta$ cells, we would like to emphasize the extremely complicated and still unknown etiopathogenesis of type 1 diabetes $[5,6]$.

\section{Genetic factors}

Genetic studies have shown that the inherited predisposition for type 1 diabetes is multi-genetic [6-9]. The human leukocyte antigen (HLA) class II genes play the most important role in this process. Their main role is to present foreign antigens with their own T lymphocytes and regulate the proper course of the immune response. HLA alleles are probably responsible for about 40-50\% of genetic risk. Significant differences have been found in the distribution of prodiabetogenic, neutral, and protective allele subtypes in different populations, which may be the reason for the wide variation in diabetes occurring in different parts of the world. Type 1 diabetes develops in people who are genetically predisposed for it, after specific autoimmune destruction of pancreatic $\beta$ cells is induced by environmental factors. Multi-gen inheritance of susceptibility includes genes responsible for the proper functioning of the immune system. Multi-center studies have shown that genetic risk score (GRS) is useful in predicting the progression of islet autoimmunity and type 1 diabetes in at-risk individuals [10]. Recently, an extensive analysis of the gene base that may be involved in the pathogenesis of type 1 diabetes has been presented by Chinese authors [11]. Triolo et al. showed in their study that monozygotic twins were more likely to have at least one positive autoantibody and were positive for GADA, IA-2A and IAA than non-identical twins or full siblings [12]. Previous studies of twins have shown that identical twins of siblings of patients with type 1 diabetes have a higher compliance rate for the development of type 1 diabetes compared with non-identical twins [13].

\section{Environmental factors}

Environmental factors, in turn, modify the response to their own antigens, but are probably not necessary to start the autoaggression process [14]. It is thought that various factors, acting through different mechanisms, can cause $\beta$-cell susceptibility to apoptosis and necrosis. It has been argued that abnormalities in the functioning of the intestinal mucosa, in the form of clinically silent enteropathy, occur even several years before the disease is revealed and may have a significant impact on the pathogenesis of type 1 diabetes. The effect of intestinal microflora, energy metabolism, inflammation, immune system, intestinal permeability, and insulin resistance on diabetes was also accepted [15-20].

\section{Mechanisms of $\beta$-cell destruction and immunological markers}

The effect of $\beta$-cell destruction is confirmed by the appearance of autoantibodies in the blood. They are the evidence for the autoimmune basis of diabetes. Islet cells antibodies (ICA), anti-insulin antibodies (IAA), anti-glutamic acid decarboxylase antibodies (GADA), anti-tyrosine phosphatase antibodies (IA2A) and anti-zinc transporter protein 8 autoantibodies (ZnT8A) have clinical significance [21-23]. According to the literature, the presence of multiple autoantibodies $(>$ or $=3$ ) is associated with a high risk of developing diabetes, while the presence of a single antibody associated with pancreatic islet cells usually has a low predictive value [24]. Islet cell antibodies (ICA) are detected in patients diagnosed with type 1 diabetes, moreover in first-degree relatives of diabetic patients, months or years before the onset of clinical symptoms [25]. Recently, Bhatty et al. presented the results of studies on the titre of ZnT8A autoantibodies in adolescents with Type 1 diabetes and their first degree relatives [26]. They found a significant association of ZnT8A titer with the development of type 1 diabetes. According to the authors, patients with ZnT8A values $\geq 9 \mathrm{ng} / \mathrm{ml}$ are 10 times more likely to develop type 1 diabetes [26]. Similar observations on the role of the ZnT8A autoantibody were recently presented by Kawasaki et al. [27]. Autoantibodies appear before the clinical appearance of diabetes. The presence of anti-GAD antibodies in high titer correlates with a high risk of developing insulin dependence and the occurrence of type 1 diabetes. It has been shown that the presence of anti-GAD antibodies can persist in high titers for many years after the diagnosis of diabetes, as opposed to anti-islet and anti-insulin antibodies, whose titers decrease quite rapidly as the disease progresses. However, circulating antibodies in the body of the patient are not the "culprits" for the destruction of insulin-producing cells. The destruction of $\beta$ cells mainly involves elements of cellular immunity, i.e. macrophages, various T lymphocyte subpopulations, and mediators of the inflammatory response (cytokines, free radicals) [28-30]. Th1 lymphocytes have been shown to have the properties that accelerate autoimmune diseases, including type 1 diabetes. In turn, Th2 lymphocytes inhibit these processes, thus fulfilling a protective role. Mannering et al. also point out the role of T cells in the pathogenesis of $\beta$-cell destruction [31]. Recently, Purcell et al. gave a comprehensive discussion of current research into the mechanisms of self-destruction of $\beta$ cells and the possibilities of monitoring these processes, which can be important in the prevention and treatment of type 1 diabetes [32]. Nakayasu et al. pointed out the need to use modern techniques to identify new biomarkers that would allow tracking various stages of the disease process [33]. Herold et al. conducted a randomized, placebo-controlled, double-blind study of teplizumab which showed that a humanized anti-CD3 monoclonal antibody delayed the progression to clinical type 1 diabetes in high-risk subjects [34]. 


\section{Conclusions}

Intensive research on the etiopathogenesis of type 1 diabetes is an extremely important field of medical research. The goal is to acquire the knowledge necessary to develop and implement causal treatment for diabetes. Effective prevention

\section{References}

1. Roep BO, Kracht MJ, van Lummel M, et al. A roadmap of the generation of neoantigens as targets of the immune system in type 1 diabetes. Curr Opin Immunol 2016; 43: 67-73. doi: 10.1016/j.coi.2016. 09.007

2. Siewko K, Maciulewski R, Zielinska-Maciulewska A, et al. Interleukin-6 and Interleukin-15 as Possible Biomarkers of the Risk of Autoimmune Diabetes Development. Biomed Res Int 2019; 2019 : 4734063. doi: 10.1155/2019/4734063.

3. Xie Z, Chang C, Zhou Z. Molecular mechanisms in autoimmune type 1 diabetes: a critical review. Clin Rev Allergy Immunol 2014; 47: 174-192. doi: 10.1007/s12016-014-8422-2

4. Zheng Y, Wang Z, Zhou Z. miRNAs: novel regulators of autoimmunity-mediated pancreatic $\beta$-cell destruction in type 1 diabetes. Cell Mol Immunol 2017; 14: 488-496. doi: 10.1038/cmi.2017.7

5. Atkinson MA, Eisenbarth GS, Michels AW. Type 1 diabetes. Lancet 2014; 383: 69-82. doi: 10.1016/S0140-6736(13)60591-7

6. Bluestone JA, Herold K, Eisenbarth G. Genetics, pathogenesis and clinical interventions in type 1 diabetes. Nature 2010; 464: 12931300. doi: 10.1038/nature08933

7. Padilla-Martínez F, Collin F, Kwasniewski M, et al. Systematic Review of Polygenic Risk Scores for Type 1 and Type 2 Diabetes. Int J Mol Sci 2020; 21: E1703.

8. Pang $H$, Luo S, Huang $G$, et al. Advances in Knowledge of Candidate Genes Acting at the Beta-Cell Level in the Pathogenesis of T1DM. Front Endocrinol (Lausanne). 2020; 11: 119. doi: 10.3389/ fendo.2020.00119

9. Todd JA, Walker NM, Cooper JD et al. Robust associations of four new chromosome regions from genome-wide analyses of type 1 diabetes. Nat Genet 2007; 39: 857-864. doi: 10.1038/ng2068

10. Redondo MJ, Geyer S, Steck AK, et al; Type 1 Diabetes TrialNet Study Group. Collaborators (1608) A Type 1 Diabetes Genetic Risk Score Predicts Progression of Islet Autoimmunity and Development of Type 1 Diabetes in Individuals at Risk. Diabetes Care 2018; 41: 1887-1894. doi: 10.2337/dc18-0087

11. Yang S, Cao C, Xie Z, et al. Analysis of potential hub genes involved in the pathogenesis of Chinese type 1 diabetic patients. Ann Transl Med 2020; 8: 295. doi: 10.21037/atm.2020.02.171

12. Triolo TM, Fouts A, Pyle L, et al. Identical and Nonidentical Twins: Risk and Factors Involved in Development of Islet Autoimmunity and Type 1 Diabetes. Diabetes Care 2019; 42: 192-199. doi: 10.2337/ dc18-0288

13. Redondo MJ, Jeffrey J, Fain PR, et al. Concordance for islet autoimmunity among monozygotic twins. N Engl J Med 2008; 359: 2849-2850 doi: 10.1056/NEJMc0805398. of type 1 diabetes in humans requires intervention at many levels, among which the most important are the "re-education" of the immune system to restore tolerance to $\beta$-cell antigens, stimulation of the population of insulin-producing cells for proliferation and regeneration, and inhibition of pro-apoptotic factor activation.

14. Knip M, Akerblom HK. Environmental factors in the pathogenesis of type 1 diabetes mellitus. Exp Clin Endocrinol Diabetes 1999; 107 Suppl 3: S93-S100. doi: 10.1055/s-0029-1212160

15. Chwalba A, Otto-Buczkowska E. Participation of the microbiome in the pathogenesis of diabetes mellitus. Clin Diabetol 2017; 6: 178-181.

16. Gianchecchi E, Fierabracci A. On the pathogenesis of insulindependent diabetes mellitus: the role of microbiota. Immunol Res 2017; 65: 242-256. doi: 10.1007/s12026-016-8832-8

17. Needell JC, Zipris D. The Role of the Intestinal Microbiome in Type 1 Diabetes Pathogenesis. Curr Diab Rep 2016; 16: 89. doi: 10.1007/ s11892-016-0781-Z

18. Tai N, Wong FS, Wen Li. The role of gut microbiota in the development of type 1, type 2 diabetes mellitus and obesity. Rev Endocr Metab Disord 2015; 16: 55-65. doi: 10.1007/s11154-015-9309-0

19. Vatanen T, Kostic AD, d'Hennezel E, et al. DIABIMMUNE Study Group. Variation in Microbiome LPS Immunogenicity Contributes to Autoimmunity in Humans. Cell 2016; 165: 842-853. doi: 10.1016/j. cell.2016.04.007

20. Zhou H, Sun L, Zhang S, et al. Evaluating the Causal Role of Gut Microbiota in Type 1 Diabetes and Its Possible Pathogenic Mechanisms. Front Endocrinol (Lausanne) 2020; 11: 125. doi: 10.3389/ fendo.2020.00125

21. Eisenbarth GS, Jeffrey J. The natural history of type $1 \mathrm{~A}$ diabetes. Arq Bras Endocrinol Metabol 2008; 52: 146-155. doi: 10.1590/ s0004-27302008000200002

22. Knip M, Siljander $H$. Autoimmune mechanisms in type 1 diabetes. Autoimmun Rev 2008; 7: 550-557. doi: 10.1016/j.autrev. 2008.04.008

23. Miao D, Yu L, Eisenbarth GS. Role of autoantibodies in type 1 diabetes. Front Biosci 2007; 12: 1889-1898. doi: 10.2741/2195

24. Franke B, Galloway TS, Wilkin TJ. Developments in the prediction of type 1 diabetes mellitus, with special reference to insulin autoantibodies. Diabetes Metab Res Rev 2005; 21: 395-415. doi:10.1002/ dmrr.554

25. Bonifacio E, Bingley PJ, Shattock M, et al. Quantification of islet-cell antibodies and prediction of insulin-dependent diabetes. Lancet 1990; 335: 147-149. doi: 10.1016/0140-6736(90)90013-u

26. Bhatty A, Baig S, Fawwad A, et al. Association of Zinc Transporter-8 Autoantibody (ZnT8A) With Type 1 Diabetes Mellitus. Cureus 2020; 12: e7263. doi: 10.7759/cureus.7263

27. Kawasaki E, Oikawa Y, Okada A, et al. Zinc Transporter 8 Autoantibodies Complement Glutamic Acid Decarboxylase and Insulinoma-Associated antigen-2 Autoantibodies in the Identification and Characterization of Japanese Type 1 Diabetes. J Diabetes Investig 2020; 11: 1181-1187. doi: 10.1111/jdi.13251 
28. Mandrup-Poulsen T. Apoptotic signal transduction pathways in diabetes. Biochem Pharmacol 2003; 66: 1433-1440. doi: 10.1016/ s0006-2952(03)00494-5

29. Pirot P, Cardozo AK, Eizirik DL. Mediators and mechanisms of pancreatic beta-cell death in type 1 diabetes. Arq Bras Endocrinol Metabol 2008, 52: 156-165. doi: 10.1590/s0004-27302008000200003

30. Tomita T. Apoptosis of pancreatic $\beta$-cells in Type 1 diabetes. Bosn J Basic Med Sci 2017; 17: 183-193. doi: 10.17305/bjbms.2017.1961

31. Mannering SI, Di Carluccio AR, Colleen M Elso CM. Neoepitopes: A New Take on Beta Cell Autoimmunity in Type 1 Diabetes. Diabetologia 2019; 62: 351-356. doi: 10.1007/s00125-018-4760-6
32. Purcell AW, Sechi S, DiLorenzo TP. The Evolving Landscape of Autoantigen Discovery and Characterization in Type 1 Diabetes. Diabetes 2019; 68: 879-886. doi: 10.2337/dbi18-0066

33. Nakayasu ES, Qian WJ, Evans-Molina C, et al. The role of proteomics in assessing beta-cell dysfunction and death in type 1 diabetes. Expert Rev Proteomics 2019; 16: 569-582. doi: 10.1080/ 14789450.2019.1634548

34. Herold KC, Bundy BN, Long SA, et al. An Anti-CD3 Antibody, Teplizumab, in Relatives at Risk for Type 1 Diabetes. N Engl J Med 2019; 381: 603-613. doi: 10.1056/NEJMoa1902226 